\title{
The Analysis of The Breast Cancer Causes at General Hospital Dr. Pirngadi Medan
}

\author{
Winda Maulinasari Nasution ${ }^{1}$ \\ Magister of Public Health, Faculty of Public Health \\ University of North Sumatera \\ Medan, Indonesia \\ winda.adelia88@gmail.com
}

\author{
Asfriyati ${ }^{2}$ \\ Department of Demography and Biostatistic \\ Faculty of Public Health, University of Sumatera Utara \\ Medan, Indonesia \\ asfriyati@gmail.com
}

\author{
Fazidah Aguslina Siregar ${ }^{3}$ \\ Department of Epidemiology, Faculty of Public Health \\ University of Sumatera Utara \\ Medan, Indonesia \\ fazidah65@yahoo.com
}

\begin{abstract}
Breast cancer is reproductive health problem which causes deaths. In Indonesia, breast cancer is the second highest new cases $43.4 \%$ with deaths $12.9 \%$. There were 2.641 women affected by breast cancer at general hospital Dr. Pirngadi Hospital, Medan, in the period of 2012-2016. The objective of the research to know of causes of breast cancer in women. This is a cases control study design was taken from the outpatients in the Oncology Polyclinic of general hospital Dr. Pirngadi, Medan, consisted of 48 people who had breast cancer and 48 people had not people breast cancer. Data was analyzed using simple and multiple logistic regression test. The result shows that there is a significant influence on the menarche age, breastfeeding duration, length of using hormonal contraception on the incidence of breast cancer, while parity did not influence it. The most significant causes that breast cancer was menarche age at $\mathrm{OR}=6.749$ (95\% CI 1.809-25.177). It is expected to have a healthy lifestyle and be aware of breast cancer risk through breast self examination as early detection and check it immediately check it to the public health centers if any early symptoms.
\end{abstract}

Keywords-breast cancer; women; analysis; causes

\section{INTRODUCTION}

Women is had the sensitive reproductive system, even the disease mostly related their physical and reproductive function and reproductive ability [1]. The survey of World Health Organization (WHO) stated that about 8-9\% women had breast cancer. Breast cancer cases as the most common cancer in women that contributes about 30\% [2].

American Cancer Society Surveillance Research estimated there were about 231.840 invasive breast cancer cases and about 60.290 cases in situ and 40.290 died [3]. In the England, between 1999-2001 cases of breast cancer increased by $6 \%$ and the 2008-2010 estimate of approximately 550,000-570,000 people living diagnosed with breast cancer. Then, in 2012 more than 41,000 new cases are diagnosed with breast cancer each year[4]. In 2012, in Perth Western Australia there were 1,423 newly diagnosed cases and about 238 women who died from breast cancer[5]. In the Jordan, breast cancer patients increased $4 \%$ annually with the highest incidence $(36.7 \%)$ all of cancers[6].

Breast cancer was in the second position in Indonesia, the first position was cervical cancer with highest percentage of the new cases about $43,3 \%$ and the percentage of mortality about $12,9 \%$ [7]. The highest prevalence was in the province of D.I. Yogyakarta about 2,4\% and the most substantial numbers of breast cancer cases was in Province of Jawa Tengah about 11.511 cases [8].

Breast cancer was a magnitude problem that can be seen through the numbers of the breast cancer clients who visited Dharmais Hospital in Jakarta about 115 clients, however in the middle of 2011, it was noted 100 people had fibroadenomamammae and 15 people positively had breast cancer [9].

In the province of North Sumatera, the numbers of breast cancer cases were about 2.682 per 100.000 with the diagnosis of prevalence about $0,4 \%$ [8]. In 2013 it was noted about 325 cases in RSUP H. Adam Malik Medan and about 444 cases in 2014 [10]. Then, there were 447 cases which is founded in Rumah Sakit Haji Medan 2014-2015 [11]. Medical Record of RS St. Elisabeth Medan 2011-2013 noted about 102 breast cancer cases which treated in the ward [12].

The main factors allegedly plays a role in the process of the breast cancer onset is estrogen hormone, but the mechanism is not clear. Estrogen hormone takes responsibility against the most secondary sexual nature of women. Estrogen in the breast can cause fat deposition in the breast glands [13]. Some factors the causes of breast cancer such as menarche age, parity, the breastfeeding duration, length of using hormonal contraception [14].

Menarche or menstruation under 12 years old takes a long period of menstruation as the result the breast will mostly expose estrogen hormone [15]. Menstruation under 12 years old get risk about 2 or 3 times than women who have menstruation over 12 years old [16]. Women with low parity have about $30 \%$ risk than multiparous women [17]. Breastfeeding exclusively can reduce the risk of breast 
cancer especially if breast milk is given for one to two yearshowever mostly women breastfeed only for a short duration [15]. The use of long term hormonal contraception have more risk about 3 times for having breast cancer than women without hormonal contraception [18]. The survey in general hospital Dr. Pirngadi Medan found 2.641 breast cancer cases in the period of 2012-2016. Hospital Dr.Pirngadi Medan as the highest breast cancer cases compared another hospital. The objective of the research to know of causes of breast cancer in women.

\section{RESEARCH METHOD}

This is a cases control study design was taken from the outpatients during January - July 2017 in the Oncology Polyclinic of general hospital Dr. Pirngadi, Medan, consisted of 48 people who had breast cancer and 48 people had not people breast cancer. The samples were selected by consecutive sampling technique using primary and secondary data. Data was analyzed using simple and multiple logistic regression test.

\section{RESULT AND DISCUSSION}

\section{A. Univariat Analysis}

From 96 respondents, mostly respondent were $<50$ years old, in the cases group about 27 respondents $(56.3 \%)$ and in the control group about 28 respondents $(58.3 \%)$. About 33 respondents $(68.8 \%)$ in the cases group were housewives and about 26 respondents in the control group $(54.2 \%)$ were housewives. The result could be seen in the following Table 1.

TABLE 1. CHARACTERISTIC OF THE CASES AND CONTROL RESPONDENTS

\begin{tabular}{|c|c|c|c|c|}
\hline \multirow{2}{*}{$\begin{array}{c}\text { Characteristic } \\
\text { of Respondents }\end{array}$} & \multicolumn{4}{|c|}{ Breast Cancer } \\
\cline { 2 - 5 } & \multicolumn{2}{|c|}{ Cases } & \multicolumn{2}{c|}{ Control } \\
\cline { 2 - 5 } & $\mathbf{n}$ & $\%$ & $\mathbf{N}$ & \% \\
\hline Age (years) & & & & \\
& & & & \\
$<50$ & 21 & 43.8 & 20 & 41.7 \\
$<50$ & 27 & 56.3 & 28 & 58.3 \\
\hline Occupation & & & & \\
& & & & \\
Housewives & 33 & 68.8 & 26 & 54.2 \\
Traders & 3 & 6.3 & 6 & 12.5 \\
Civil Servant & 7 & 14.6 & 9 & 18.8 \\
Entrepreneur & 3 & 6.3 & 4 & 8.3 \\
Farmers & 2 & 4.2 & 3 & 6.3 \\
\hline
\end{tabular}

From 96 respondents in the cases group, mostly 39 respondents $(81.3 \%)$ had menarche age $<12$ years old and mostly 28 respondents $(58.3 \%)$ were $\geq 12$ years old in the control group. Whereas Parity, the numbers of respondents' children in cases group who had $>2$ children in the cases group about 25 respondents $(52.1 \%)$ and about 30 respondents $(62.5 \%)$ in the control group. Likewise the duration of breastfeeding in the cases group mostly respondents breastfeed their babies for $<6$ months about 33 respondents $(68.8 \%)$ and in the control group about 38 respondents $(79.2 \%)$ breastfed their babies for $\geq 6$ months.
Mostly 34 respondents $(70,8 \%)$ in the cases group had using hormone contraceptive for $\geq 5$ years and 37 respondents (77.1\%) in the control group had using hormone contraceptive for $<5$ years. The results can be seen in the following Table 2 .

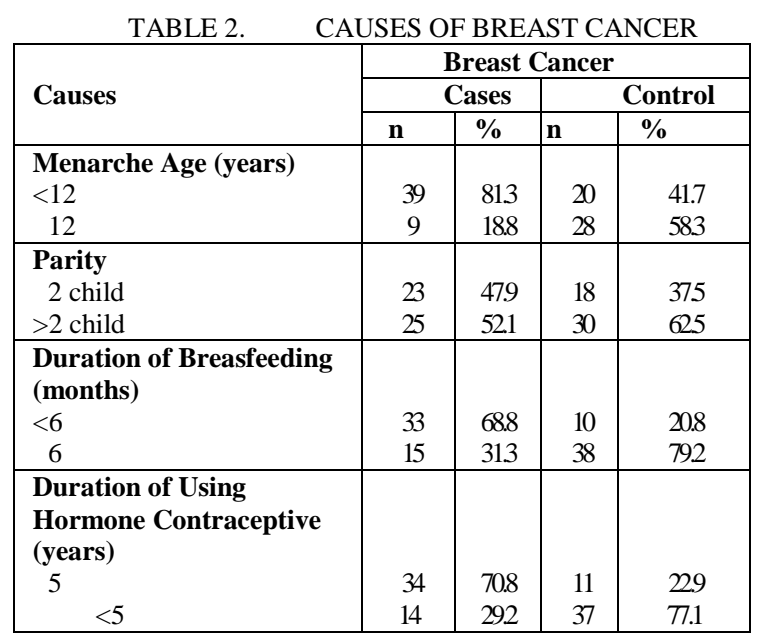

\section{B. Bivariat Analysis}

The result of the simple logistic regression test showed that there was a significant influence between menarcheageto the breast cancer. It also found that the OR 6.067 (95\% CI 2.407-15.291) it meant the women had early menarche at age $<12$, they had risk for having breast cancer about 6.067 times than women had menarche at the age $\geq 12$.

The result of simple logistic regression test showed that there was no significant influence between parity to the breast cancer.

The result of simple logistic regression test on the length of breastfeeding showed that there was a significant influence between the duration of breastfeeding to the breast cancer. It also found that OR $8.360(95 \%$ CI 3.311-21.107) it meant that the women who had breastfed for $<6$ months had risk about 8,360 times for having breast cancer than women who had breastfed for $\geq 6$ months.

The result of simple logistic regression test on the duration of hormonal contraception showed that there was a significant influence between the duration of hormonal contraception to the breast cancer. It also found that OR 8.169 (95\%CI 3.266-20.431) it meant that the women who had hormonal contraception for $\geq 5$ years had risk about 8.169 times having breast cancer than the women who had hormonal contraception for $<5$ years. The result can be seen in the following table 3 .

\section{Multivariat Analysis}

The variable that dominantly causes breast cancer in general hospital Dr. Pirngadi Medan after adjusted with the other variables was menarche age OR 6.749 (95\%CI 1.80925.177 ) meant women who had first menarche at age $<12$ potentially having breast cancer about 6.749 times than women who had first menarche at the age $\geq 12$. The result can be seen in the following table 4 . 
TABLE 3. BIVARIATE ANALYSIS WITH SIMPLE LOGISTIC REGRESSION REST

\begin{tabular}{|c|c|c|c|c|c|c|}
\hline \multirow{3}{*}{ Causes } & \multicolumn{4}{|c|}{ Breast Cancer } & \multirow{3}{*}{$\begin{array}{c}\text { Crude } \\
\text { OR (95\% CI) }\end{array}$} & \multirow{3}{*}{$p$} \\
\hline & \multicolumn{2}{|c|}{ Cases } & \multicolumn{2}{|c|}{ Control } & & \\
\hline & $\mathbf{n}$ & $\%$ & $\mathbf{n}$ & $\%$ & & \\
\hline Menarche Age (years) & & & & & & \\
\hline$<12$ & 39 & 813 & 20 & 41.7 & $6.067(2.407-15.291)$ & 0.001 \\
\hline$\geq 12$ & 9 & 18.8 & 28 & 583 & & \\
\hline Parity & & & & & & \\
\hline$\underline{s}$ child & 23 & 479 & 18 & 375 & $1.533(0.680-3.460)$ & 0.303 \\
\hline$>2$ child & 25 & 52.1 & 30 & 625 & & \\
\hline $\begin{array}{l}\text { Duration of Breasfeeding } \\
\text { (months) }\end{array}$ & & & & & & \\
\hline$<6$ & 33 & 68.8 & 10 & 20.8 & $8.360(3.311-21.107)$ & 0.001 \\
\hline 26 & 15 & 313 & 38 & 792 & & \\
\hline $\begin{array}{l}\text { Duration of Using } \\
\text { Hormone Contraceptive } \\
\text { (years) }\end{array}$ & & & & & & \\
\hline 25 & 34 & 70.8 & 11 & 229 & $8.169(3.266-20.431)$ & 0.001 \\
\hline$<5$ & 14 & 292 & 37 & 7.1 & & \\
\hline
\end{tabular}

TABLE 4. MULTIVARIATE ANALYSIS WITH MULTIPLE LOGISTIC REGRESSION TEST

\begin{tabular}{|c|c|c|c|c|c|c|}
\hline \multirow{3}{*}{ Causes } & \multicolumn{4}{|c|}{ Breast Cancer } & \multirow{3}{*}{$\begin{array}{l}\text { Adjusted } \\
\text { OR (95\% CI) }\end{array}$} & \multirow{3}{*}{$p$} \\
\hline & \multicolumn{2}{|c|}{ Cases } & \multicolumn{2}{|c|}{ Control } & & \\
\hline & $\mathbf{n}$ & $\%$ & $\mathbf{n}$ & $\%$ & & \\
\hline $\begin{array}{l}\text { Menarche Age (years) } \\
\quad<12 \\
\geq 12\end{array}$ & $\begin{array}{l}39 \\
9\end{array}$ & $\begin{array}{l}81,3 \\
18.8\end{array}$ & $\begin{array}{l}20 \\
28\end{array}$ & $\begin{array}{l}41.7 \\
583\end{array}$ & $6.749(1.809-25.177)$ & 0.004 \\
\hline $\begin{array}{l}\text { Duration of Breasfeeding (months) } \\
<6 \\
\square 6\end{array}$ & $\begin{array}{l}33 \\
15\end{array}$ & $\begin{array}{l}68.8 \\
313\end{array}$ & $\begin{array}{l}10 \\
38\end{array}$ & $\begin{array}{l}20.8 \\
792\end{array}$ & $5.560(1.732-17.851)$ & 0.004 \\
\hline $\begin{array}{l}\text { Duration of Using Hormone } \\
\text { Contraceptive (years) } \\
\quad 25 \\
<5\end{array}$ & $\begin{array}{l}34 \\
14\end{array}$ & $\begin{array}{l}70.8 \\
292\end{array}$ & $\begin{array}{l}11 \\
37\end{array}$ & $\begin{array}{l}229 \\
7.1\end{array}$ & 4.300 (1358-13.612) & 0.013 \\
\hline
\end{tabular}

Normal menstrual cycles occur every 22-35 days and the first time by women at the age of 12 to 16 years. With a length of menstruation for 2-7 days. Early menarche in a woman can be caused by a variety of factors: factors by genetic factors, environmental factors, and lifestyle factors [19] [1]. A woman who experiences menstruation at an early age before the age of 12 years then the woman will have an increased risk of breast cancer. Because the sooner a woman experiences puberty then exposure to estrogen hormone in the body will become faster too [20].

Menarche $<12$ years may increased the risk of breast cancer because it exposed the higher estrogen hormone levels. Eventually, it will be continue during menstruation and decreased until menopause [21]. This study is consistent with Kamath showing that there is an effect of menarche age $<12$ years risk 2 times of breast cancer compared with menarche $\geq 12$ years old [22]-[24].

The first age at the first pregnancy is a window of initiation of breast cancer development. Women who give birth to their first child at age 30 and above have a higher risk of risk than women who gave birth to their first child when they were younger. Having more than one child at the earning age of pregnancy can reduce your risk of developing breast cancer. This is because pregnancy reduces the total number of women's lifelong menstrual cycles [15] [25].

Based on table 3 Mohite's showed that there was no significant effect between parity and breast cancer incidence with $p=0.956$ [26]. However, this study was not in line with Kumar who stated that the number of parity $\mathcal{S}$ had an effect on breast cancer OR 2.643 (95\%CI 1.446-4.831) [27] [28].

The breast cancer cases will be great against women who do not breastfeed. This condition is influenced by hormonal mechanisms. In the body, the hormone prolactin will be exposure estrogen in large quantities and in a long time can trigger breast cancer. The longer breastfeeding time, the greater protective this effect to against existing cancer and it turns out the cancer risk decreases $4.3 \%$ at women who are breastfeeding [17].

Based on table 3 and 4, AichRanen's research shows that long breastfeeding is at risk of 2 times against breast cancer [29][30]. However, it is not in research with Devi which shows that there is no significant effect of $p=0.057$ between women who breastfed babies $<6$ months with women who breastfed babies $\searrow 6$ months [31]. 
The use of hormonal contraception is too long can disrupt the balance of the hormone estrogen in the body resulting in the occurrence of normal cell changes become abnormal. The cause of breast cancer incidence is not known for certain, but the use of hormonal contraceptives in the long term can lead to breast cancer incidence. This is because the growth of breast tissue is very sensitive to estrogen so women exposed to estrogen in a long time will have a big risk to breast cancer [17]. Based on table 3 and 4 in accordance with Hosseinzadeh also stated that the duration of hormonal contraceptive use for $\geq 5$ years had an effect on breast cancer with a risk of 3.57 times compared with women taking hormonal contraceptive $<5$ years with OR value 3.57 (95\% CI 2.07-6.15) [32][33].

\section{CONCLUSION}

The study finds that the causes of breast cancer in general hospital Dr. Pirngadi Medan was influenced by menarche age, breastfeeding duration, and length of using hormonal contraception. Parity does not affect to the breast cancer in general hospital Dr. Pirngadi Medan. Menarche age is the dominant variable that cause of breast cancer in general hospital Dr. PirngadiMedan with with OR=6.749 (95\%CI 1.809-25.177).

\section{RECOMMENDATION}

Recommended to the public to have a healthy life style and awareness against the risk factor of breast cancer. Performing breast self-examination (BSE) as routine early detection is useful to prevent early onset of breast cancer. Women should examine their selves to the health service immediately when there are early signs and symptoms of breast cancer.

\section{ACKNOWLEDGMENT}

Thank you to the Director of general hospital Dr.Pirngadi Medan, head of medical record and head of Oncology Polyclinic the general hospital Dr.Pirngadi Medan and specially to breast cancer patients for their participation in this research.

\section{REFERENCES}

[1] E. Kusmiran, Kesehatan Reproduksi Remaja dan Wanita. Jakarta : Salemba Medika, 2014.

[2] Yayasan Kanker Indonesia, "Penderita kanker Indonesia semakin meningkat," in press.

[3] American Cancer Society, Breast Cancer Facts \& Figures 2015 2016. Atlanta : American Cancer Society Inc., 2015.

[4] E. A. Suzanne, "Critical research gaps And translational priorities for the succesful prevention and treatment of the breast cancer," Biomed Central, in press.

[5] Cancer Council Australia, "Understanding breast cancer a guide for people with cancer, their families and friends," in press.
[6] L. N. Kawar, R. N. PhD, CNS, "Knowledge about breast cancer and negative influences affecting breast cancer screening among women in Jordan," International Journal of Humanities and Social Science School of Nursing California State University Long Beach 1250 Bellflower Blvd Long Beach, CA 90840, USA, Vol. 2 No. 18, October 2012.

[7] Globocan, "Estimated Cancer Incidence Mortality And Prevalence World Wide In 2012," unpublished.

[8] Kementerian Kesehatan RI, "Stop kanker," in press.

[9] Yayasan Kanker Indonesia, "Penderita kanker Indonesia semakin seningkat," in press.

[10] D. Maysarah D, "Analisis faktor risiko kanker payudara di rumah sakit umum pusat Haji Adam Malik Medan," Minat Studi Epidemiologi Fakultas Kesehatan Masyarakat Universitas Sumatera Utara, Tesis, 2016.

[11] F. H. Lingga, "Karakteristik penderita kanker payudara rawat inap di rumah sakit Haji Medan tahun 2014 - 2015," unpublished.

[12] L. E. Sinaga L.E, "Karaktristik penderita kanker payudara yang dirawat inap di rumah sakit St. Elisabeth tahun 2011 - 2013," Jurnal Gizi, Kesehatan Reproduksi, Epidemiologi Universitas Sumatera Utara, vol. 1 no.4, 2014.

[13] Y. Sandra, Melatonin dan Kanker Payudara, Majalah Kesehatan Pharma Medika, vol. 3, no.2, pp. 286-291. 2011.

[14] Profil Kesehatan Indonesia, Fibroadenoma Mammae pada Remaja Indonesia. Jakarta : Depkes RI, 2014.

[15] Z. Pamungkas, Deteksi Dini Kanker Payudara Kenali Sebab - Sebab dan Cara Antisipasinya. Yogyakarta : Buku Biru, 2011.

[16] P.T E. Suyatno, Bedah Onkologi Diagnostik dan Terapi. Jakarta : Sagung Seto, 2014.

[17] I. Rasjidi Imam, Deteksi Dini dan Pencegahan Kanker pada Wanita. Jakarta : Sagung Seto, 2011.

[18] A. T. Dewi Gusti dan Y. L. Hendrati, "Breast cancer risk analysis by the use of hormonal contraceptives and age of menarche," Jurnal Berkala Epidemiologi, Departemen Epidemiologi Fakultas Kesehatan Masyarakat, Universitas Airlangga, Surabaya, Jawa Timur, Indonesia, vol. 3, no. 1 Januari 2015, pp : $12-23,2015$.

[19] M. T. Anggraini, "Hubungan antara usia saat timbulnya menarche dengan usia saat terjadinya menopause wanita di kecamatan Kartasura," unpublished.

[20] N. S. Mulyani dan Nuryani, Kanker Payudara dan PMS Kehamilan. Yogyakarta : Nuha Medika, 2013.

[21] Karima, Faktor - Faktor Yang Berhubungan Dengan Kejadian Kanker Payudara Wanita di Rumah Sakit Umum Pusat Nasional (RSUPN) dr. Cipto Mangunkusumo Jakarta : Universitas Indonesia, 2013.

[22] R. Kamath, "A study on risk factors of breast cancer among patients attending the tertiary care hospital," In Udipi District, Indian J Community Med., vol. 38, issue 2, pp: 95-99, 2013.

[23] Iqbal Javaid, 2015. Risk Factors For Premenopausal Breast Cancer In Bangladesh, Hindawi Publishing Corporation International Journal Of Breast Cancer Volume 2015, ID612042, 7 Pages.

[24] F. Z. Laamiri, A. Bouayad, N. Hasswane, M. Mrabet, and B. Amina, "Risk factors for breast cancer of differentAge groups : Moroccan data," Journal of Obstetrics and Gynecology, Faculty of Medicine and Pharmacy/Research Team in Maternal and Child Health and Nutrition, Mohammed University, Rabat, Morocco, vol. 5, pp: $79-$ 87, 2015.

[25] T. Nugroho Taufan, Asi dan Tumor Payudara. Yogyakarta : Nuha Medika, 2011.

[26] V. R. Mohite, "Reproductive risk factors and breast cancer a case control study from rural India", Bangladesh Journal Of Medical Science, in press.

[27] K. N. Babita, "Breastfeeding reduces breast cancer risk a case control study in north India", Int J Prev Med., in press.

[28] A. Balekouzou, "Reproductive risk factors associated with breast cancer in women in Bangui a case control study, BMC Women Health, in press.

[29] Aich Ranen, "Relevance of risk of breast cancer in women An eastern Indian scenario," Journal Of Cancer Research And Therapeutics, Volume 12 Issue 1, 2017.

[30] Bhadoria, "Reproductive factors and breast cancer a case control study in tertiary care hospital of nort india," March 14, 2017, 
[31] Devi Nirmala, "A case control study on risk factors Of breast cancer among women attending MNJ cancer hospital," Hyderabad, International Journal Of Biomedical And Advance Research, 2016.

[32] Hosseinzadeh Mina, Ziaei1 Jamal, Mahdavi Nader, Aghajari, Vahidi Maryam, Fateh Asghari Elnash, "Risk factors for breast cancer in Iranian women: a hospital-based case control study in Tabriz, Iran,"
Department of Nursing, Hematology and Oncology Research Center, Tabriz University of Medical Sciences, Tabriz. J. Breast Cancer, vol. 17, issue 3. Pp : 236-243, September 2014.

[33] Giudici Fabiola, "Breastfeeding a reproductive factor able to reduce the risk of luminal B creast cancer in premenopausal white women," Europen Journal Of Cancer Prevention 2017, vol 26, issue 3, 2017 